\title{
ЛОГИСТИЧЕСКАЯ ИНФРАСТРУКТУРА КАК ФАКТОР КОНКУРЕНТОСПОСОБНОСТИ СУБЪЕКТОВ МАЛОГО ПРЕДПРИНИМАТЕЛЬСТВА И ФЕРМЕРСКИХ ХОЗЯЙСТВ
}

\author{
(c) 2020 Поповский Юрий Николаевич \\ соискатель \\ ФГУП «ВНИИ «Центр», Россия, Москва \\ E-mail: agor80@yandex.ru
}

\section{(c) 2020 Пекуровский Дмитрий Александрович}

кандидат ветеринарных наук, доцент кафедры управления АПК и сельскими территориями Российская академия кадрового обеспечения агропромышленного комплекса, Россия, Москва

E-mail: pekurovskii@mail.ru

\section{(C) 2020 Шурукова Елена Евгеньевна аспирант \\ ИПУ РАН, Россия, Москва \\ E-mail: agor80@yandex.ru}

Статья посвящена вопросам экономической деятельности небольших фермерских хозяйств, ориентируемых на производство и продажу собственной продукции. В качестве основной проблемы деятельности выделены сложности сбыта. Автор приходит к выводу о необходимости формирования единой логистической инфраструктуры, развитии механизмов кооперации, повышении уровня информационного обеспечения фермеров.

Ключевые слова: агропромышленный комплекс; крестьянские фермерские хозяйства; личные подсобные хозяйства; фермерская продукция; хозяйства населения.

Сельское хозяйство традиционно представлено как крупными производителями, так и небольшими, но многочисленными фермерскими хозяйствами. Экономика фермерских хозяйств обладает рядом специфичных особенностей, которые как создают дополнительные возможности для занятости, так и порождают необходимость в государственной поддержке.

Рынок сельскохозяйственной продукции отличается неоднородным составом участников. Среди производителей сельскохозяйственной продукции имеются как крупные агропромышленные предприятия, так и небольшие фермерские хозяйства. Социально-экономическое значение небольших хозяйств состоит в следующем:

- Обеспечение занятости сельского населения (производство собственной продукции является одним из традиционных видов деятельности в сельской местности);

- Обеспечение продовольственной безопасности сельской местности;

- Сохранение и развитие животноводческих пород и культур растениеводства (крупные предприятия сосредоточены на наиболее продуктивных породах и культурах, что позволяет внедрять передовые достижения генетики. В небольших же хозяйствах встречается большое количество пород и культур).

Проблематика ведения деятельности фермерских хозяйств в первую очередь представлена проблемой сбыта и, как одной из ее составляющих, проблемой высокой себестоимости продукции.

Высокая себестоимость продукции в первую очередь связана с фактором доступа к передовым промышленным и генетическим технологиям $[4,5]$. Использование передового оборудования в небольших хозяйствах практически невозможно по причине его высокой стоимости и длительного срока окупаемости. Так, в частности, многие фермеры не имеют возможности самостоятельного производства комбикормов для собственных нужд (использование комбикормов дает больший прирост в весе по сравнению с зерносмесью за аналогичный период времени и снижает риски заболеваемости). К тому же, в отдельных областях животноводства тре- 
буется использование гибридных пород (к примеру, бройлеров), которые не передают своим потомкам необходимых качеств (этим объясняется дороговизна выращенных фермерами бройлеров, поскольку они вынуждены закупать птенцов и инкубационные яйца). Несмотря на то, что фермеры чаще всего не несут больших организационно-управленческих и бухгалтерских издержек (а также не обременены большой налоговой нагрузкой), высокая себестоимость продукции и небольшие обороты приводят к высокой цене продукции. То есть, проблема сбыта существенно осложняется высокой ценой продукции.

Несмотря на вопрос себестоимости продукции, ключевым характером все же обладает проблема сбыта, поскольку фермерская продукция имеет свою нишу и своих покупателей [3]. Как справедливо пишет исследователь Л.В.Волков, основным ограничителем развития фермерского хозяйства «выступает не отсутствие спроса на сельскохозяйственную продукцию и продовольствие, а отсутствие каналов продаж и инфраструктуры сбыта». Для решения данной проблем Л.В.Волков предлагает следующее: развитие потребительской кооперации; субсидирование процентных ставок по кредитам на реализацию инвестиционных проектов, направленных на создание инфраструктуры; стимулирование создания компаний, выполняющих функции интеграции и координации деятельности фермерских хозяйств и других форм малого сельского бизнеса [1]. В основе инфраструктуры лежат процессы информационного обмена.

Как уже было сказано выше, рыночная информация важна для всех участников рынка, однако наибольшей значимостью она обладает для самих производителей по причине сопряженности с другими издержками $[2,11]$. В конечном счете, наибольшие риски ложатся именно на производителей, которым необходимо в ограниченных сезонных условиях произвести ту или иную культуру. В области животноводства распределение рыночных структур иное, нежели в растениеводстве, однако принципиальная значимость рыночной информации сохраняется [17]. Здесь следует учитывать то обстоятельство, что прокорм животных в зимних условиях дорогостоящ. В животноводстве не такие серьезные сезонные колебания, однако жесткие климатические условия усложняют производственный процесс, и обладание актуальной и своевремен- ной информации необходимо для функционирования организаций-производителей животноводческой продукции.

Следующее, что необходимо отметить по рассматриваемой теме - несовершенство процессов обмена информации между участниками экономических отношений. Данные сложности носят институциональный характер. Как пишет Т.В.Остапенко, в целях минимизации трансакционных издержек в агропродовольственном комплексе необходимо упорядочить деятельность торгово-посреднических структур, сформировать кластеры, создать контрактные фирмы, развить оптовые продовольственные рынки [10]. Наиболее активно в настоящее время протекает процесс кластеризации. В рамках кластеров образуются дополнительные каналы коммуникации, что снижает издержки по поиску контрагентов. Данное обстоятельство весьма значимо, поскольку в сельском хозяйстве имеется большое количество различных рыночных структур, поскольку производство, заготовка и реализация сельскохозяйственной продукции включает в себя деятельность большого числа организаций. В особенности влияние информационных потоков сказывается на контрактации.

Выраженный сезонный характер логистики в совокупности с характерными для России высокими логистическими издержками существенно осложняет логистическую деятельность в общем и целом [5]. Данное утверждение характерно для всех групп производителей, при этом крупные предприятия в перспективе могут ее решить посредством функционирования специализированных логистических объектов. В связи с этим получило распространение создание единых логистических систем в рамках агропромышленных комплексов. А.Л.Носов отмечает, что в данных системах при организации логистической деятельности создаются участки и службы приема и первичной обработки продукции, лабораторного контроля, разделки, переработки, охлаждения, заморозки, хранения, упаковки, транспортировки [9]. Для небольших хозяйств требуется иной подход.

При рассмотрении сбыта фермерской продукции необходимо учитывать, что фермерские хозяйства имеют различную институциональную природу. С этой позиции следует выделить:

- Крестьянские фермерские хозяйства $(\mathrm{K} Ф \mathrm{X})$;

- Личные подсобные хозяйства (ЛПХ); 
- Кооперативные объединения.

Наибольшее распространение получили КФХ и ЛПХ, однако здесь необходимо отметить, что они не составляют основу хозяйств населения. На рис. 1 показана структура продукции сельского хозяйства по категориям хозяйств [13]. Рост КФХ сопровождается стремительным снижением выпуска продукции хозяйствами населения, что объясняется высокой себестоимостью фермерской продукции (многие сельские жители не имеют экономической возможности занятия сельским хозяйством даже для собственных нужд).

Как указывают В.И.Кудряшов, С.С.Сушенцова, М.В.Ивлев, главной проблематикой экономической деятельности КФХ является отсутствие эффективно действующих на основе рыночных принципов свободной конкуренции инфраструктурных субъектов аграрного рынка [7].

А.В.Кучумов, Е.С.Воробьева указывают на необходимость создания региональных маркетинговых стратегий для продукции КФХ при участии государства, позволявших бы организовать централизованных сбыт продукции КФХ, определить строгое позиционирование продукции, создать интернет-ресурс по продаже продукции, а также заключать договоры прямых поставок с крупными торговыми сетями [8].

Одним из наиболее перспективных вариантов организации сбыта продукции является создание кооперативных объединений. Кооператив является более крупным социальным субъектом и имеет потенциально большее количество возможностей для организации сбыта. С целью содействия деятельности кооперати- вов создаются и функционируют региональные Центры компетенций в сфере сельскохозяйственной кооперации.

Центры компетенций в сфере сельскохозяйственной кооперации создаются на региональном уровне. Одной из отличительных особенностей данных центров является наличие (как правило) стратегической программы деятельности и стандарта деятельности. Центры оказывают информационно-консультационные услуги физическим и юридическим лицами [14]. Направления деятельности Центров соответствуют поставленным перед ними Стандартом целям:

- Участие в разработке и реализации региональных государственных программ, направленных на развитие АПК, поддержку малого и среднего предпринимательства в АПК, сельскохозяйственной кооперации;

- Содействие созданию на территории субъекта РФ субъектов МСП, СХК;

- Предоставление услуг для повышения эффективности деятельности субъектов МСП;

- Повышение информированности граждан, ведущих ЛПХ, субъектов МСП о преимуществах объединения в СХК;

- Оказание информационных, консультационных, методических услуг субъектам МСП, СХК и ЛПХ;

- Организация сопровождения деятельности микро-, малых и средних сельскохозяйственных;

- Анализ и мониторинг деятельности субъектов МСП и СХК.

Центры выполняют информационноконсультативную функцию. Вместе с этим, это не решает собственно каналов сбыта. Между тем,

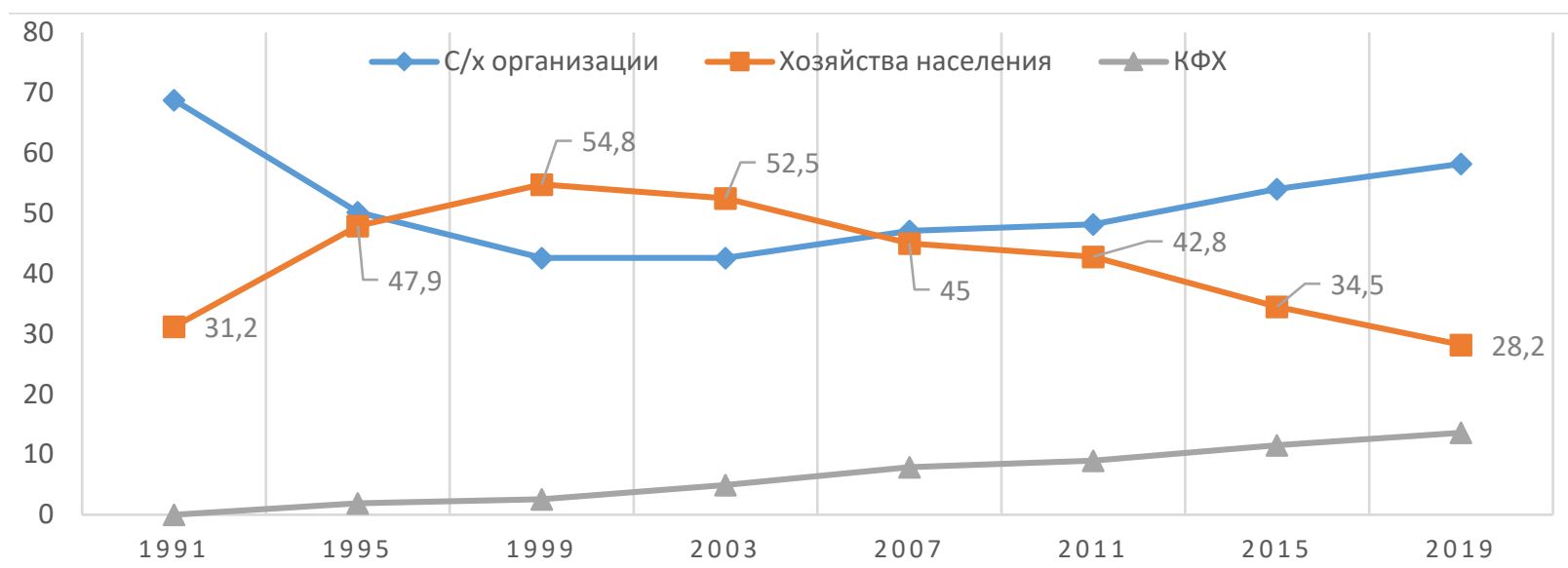

Puc. 1. Структура сельского хозяйства по категориям хозяйств по РФ за период 1991-2019 годы 
для сбыта возникают альтернативные каналы. М.М.Трясцин, В.И.Кузнецов среди альтернативных форм сбыта фермерской продукции выделяют электронную торговлю фермерской продукцией, экобазары, вендинг, непосредственные поставки в розничные магазины [15]. Очевидно, что полноценное функционирование альтернативных каналов невозможно без решения задач институционального плана.

Потребители приходят на производственное предприятие или ферму, чтобы купить продукцию, а в некоторых случаях сами собирают ее. Примеры включают продажу овощей с огорода производителя, продажу яиц с предприятия по производству яиц, прямую продажу домашнего скота и операции по самовывозу ягод, фруктов и цветов. В общем, нет ограничений на типы товаров, которые могут быть проданы таким образом, если есть желающие покупатели. Иногда между фермером и потребителем находится ограниченное количество посредников. Мы полагаем, что здесь есть институциональная возможность для создания коротких цепочек продаж.

На формирование коротких цепочек продаж позитивно воздействуют следующие факторы:

- Географическая близость (физическая близость, измеряется как расстояние между производителями и потребителями);

- Социальная близость (прямые (с очень небольшим количеством посредников) и доверительные отношения между производителем и потребителем, которые знают друг друга и продукт, солидарность между производителями и потребителями, гражданское участие в местной продовольственной системе);

- Экономическая близость (происходят рыночные обмены, и деньги циркулируют в пределах сообщества или определенной местности).

Кооперативные объединения - один из основных путей решения сбытовой проблемы. Кооперативы особенно хороши для фермеров, которым не нравится прямой маркетинг или у которых нет навыков работы с людьми. Кооперативы работают, собирая вместе группу небольших производителей, которые производят один и тот же продукт. Они объединяют свою продукцию, чтобы обеспечить объем, необходимый основным покупателям. Продажа осуществляется продавцом из кооператива, что дает фермерам больше времени на производство. Недостатком является то, что фермеры не будут получать розничную цену за свою продукцию (хотя они могут получить небольшую надбавку за качество), а часть их прибыли снижается за счет различных издержек (включая зарплату продавца). Здесь следует отметить, что кооперативные объединения могут осуществляться в двух основных формах:

- Производственные кооперативы;

- Потребительские кооперативы.

Согласно ст. 1 ФЗ «О производственных кооперативах» производственным кооперативом является добровольное объединение граждан на основе членства для совместной производственной и иной хозяйственной деятельности, основанной на их личном трудовом и ином участии и объединении его членами (участниками) имущественных паевых взносов [16]. Что же касается потребительских кооперативов, то одной из их непосредственных задач является не только обеспечение членов потребительских обществ товарами, но и производство пищевых продуктов с последующей их реализацией через организации розничной торговли [6]. Полагаем, что производственная кооперация поможет наиболее эффективно решать вопрос сбыта среди тех фермеров, выпуск продукции которых превышает их собственные нужды. Потребительская же кооперация может быть ориентирована больше на хозяйства населения, стремящиеся к производству, обмену и закупке продукции для удовлетворения личных нужд.

Таким образом, для решения сбытовой проблемы небольших фермерских хозяйств представляется необходимым:

- Последовательное развитие кооперации в сельском хозяйстве;

- Формирование коротких цепочек продаж;

- Развитие логистической инфраструктуры;

- Повышение уровня информационной обеспеченности фермеров;

- Развитие альтернативных каналов сбыта продукции;

- Содействие органов государственной власти и местного самоуправления по выводу фермерской продукции на рынки и в розничные сети. 


\section{Библиографический список}

1. Волков Л. В. Развитие крестьянско-фермерских хозяйств и малых форм хозяйствования в России // Финансовые рынки и банки. 2020. № 3. С. 121-127.

2. Горохова А.Е. Факторы развития промышленных предприятий в условиях становления постиндустриальной экономики // Экономика и предпринимательство. 2014. № 12-2 (53). С. 870-873

3. Ефремов А.А. Лизинговые отношения в формировании цепей поставок // Проблемы современной экономики. 2011. № 1 (37). С. 145-148

4. ЕфремовА.А. Логистическая стратегия развития сетевых структурлизинга//Известия Санкт-Петербургского университета экономики и финансов. 2012. № 1 (73). С. 68-74.

5. Ефремов А.А., Щербаков В.В. Инвариантность сетевых форм организации логистических цепей // Вестник Астраханского государственного технического университета. Серия: Экономика. 2011. № 2. С. $72-79$

6. Закон РФ от 19.06.1992 № 3085-1 «О потребительской кооперации (потребительских обществах, их союзах) в Российской Федерации» (ред. от 02.07.2013) / Ведомости СНД и ВС РФ, 30.07.1992, № 30, ст. 1788.

7. Кудряшев В. И., Сушенцова С. С., Ивлев М.В. О развитии инфраструктуры сбыта продукции крестьянских (фермерских) хозяйств // Никоновские чтения. 2009. № 1 (1). С. 39-45.

8. Кучумов А. В., Воробьева Е. С. Развитие крестьянских (фермерских) хозяйств в рамках достижения доктрины продовольственной безопасности // Московский экономический журнал. 2018. № 4. С. 1-9.

9. Носов А. Л. Логистика в агропромышленном комплексе // Концепт. 2016. № 11. С. 1-5.

10. Остапенко Т.В. Роль трансакционных издержек в экономическом анализе агропродовольственного комплекса // Никоновские чтения. 2013. № 18. С. 409-411.

11. Секерин В.Д. Горохова А.Е.Инновационная среда как фактор эффективности коммерциализации инноваций // Известия Московского государственного технического университета МАМИ. 2014. Т. 5. № 2 (20). С. 39-43

12. Секерин В.Д., Горохова А.Е., Лаптева Д.Я., Калинкина Т.М.Научно-техническая информация как фактор развития общества // Известия МГТУ «МАМИ».-2013. № 1 (15), т.5.-С. 136-141

13. Сельское хозяйство, охота и лесное хозяйство [Электронный ресурс] / Росстат. URL: https://rosstat.gov.ru/ enterprise_economy (дата обращения 02.08.20).

14. Стандарт деятельности центров компетенций в сфере сельскохозяйственной кооперации и поддержки фермеров (утв. проектным комитетом по национальному проекту «Малый бизнес и поддержка индивидуальной предпринимательской инициативы», протокол от 21.03.2019 № 1) // Доступ из СПС «Гарант».

15. Трясцин М. М., Кузнецов В. И. Инновационные методы сбыта продукции как пути повышения эффективности деятельности фермерских хозяйств // Пермский аграрный вестник. 2014. № 2 (6). С. 70-77.

16. Федеральный закон от 08.05.1996 № 41-Ф3 «О производственных кооперативах» (ред. от 31.07.2020) // С3 РФ от 13 мая 1996 г. № 20 ст. 2321.

17. Danko T.P., Ekimova K. V., Bolvachev A.I., Zarova E. V., Shemetkova O. L., Solovyova M. G., Sekerin V.D. ASSESSMENT OF THE COMPETITIVE POTENTIAL OF THE REGION THROUGH AN INTEGRATED SYSTEM OF RATING POSITIONING // International Journal of Economic Research. 2016. T. 13. № 6. C. 2361-236 